Section Editors

David C. Spencer, MD

Steven Karceski, MD

\title{
Migraine frequency and risk of cardiovascular disease in women
}

Eve Klein, MD

David Spencer, MD
Previous studies have shown that people who suffer from migraine headaches are more likely to also have cardiovascular disease, such as stroke and heart attack. ${ }^{1,2}$ We do not know, however, exactly how migraines are related to cardiovascular disease. We believe that migraines cause changes in blood flow in the brain. Strokes occur when a part of the brain receives no blood flow at all, and heart attacks occur when the heart muscle is starved of blood. Because both migraines and cardiovascular disease involve changes in blood flow, it is reasonable to think that people who have more frequent migraines would be at higher risk for strokes and heart attacks.

WHAT DID THE AUTHORS STUDY? The authors of a study published in this issue of Neurology ${ }^{\circledR}$ reviewed the records of 27,798 female health professionals aged 45 and older with no known cardiovascular disease. ${ }^{3}$ Of these women, 3,568 had migraines. Compared with other studies of this type, this is a large number of subjects; having more subjects makes a study more reliable. Medical information about these women was recorded during a 12-year period. The researchers asked whether the women experienced migraines less than once a month, every month, or every week. They also tracked whether the women developed any cardiovascular disease during the 12 -year period. Using this information, the authors compared the risk of cardiovascular disease with the frequency of migraine to determine how the two might be related.

WHAT DID THE RESULTS SHOW? The authors found very different results depending on whether or not women had migraine auras. A migraine aura is an early warning symptom of a migraine that often involves changes in vision. In women whose migraines did not include an aura, they found no significant increase in risk of cardiovascular disease compared with women who had no migraines at all. However, when the authors looked only at women whose migraines included an aura, they found that these women did have an increased risk of cardiovascular disease. Women whose migraines with aura occurred less than once a month had more than twice the risk of heart attack than women without migraines and also had elevated stroke risk. Women whose migraines with aura occurred at least once a week had more than 4 times the risk of stroke compared to women without migraines.

Although these changes in risk sound big, it is important to remember that the actual numbers of people who developed cardiovascular disease are small. For example, of the 180 women with weekly migraines, only 2 had heart attacks and 4 suffered strokes during the 12 years of the study. Also important to remember is that there are many other risk factors for developing strokes and heart attacks and that the women in this study did not have equal risk factors. For example, the women who had weekly migraines also had lower cholesterol, less smoking, and less alcohol use, but higher blood pressure and more hormone replacement use than the women with less frequent or no migraines. The authors used statistics to try to control for these differences, but this uneven balance of risk factors could make the results less reliable.

\section{WHY IS THIS INFORMATION IMPORTANT?}

This information is important for patients and their loved ones because it tells us that some women with migraines - especially those with aura - may be at higher risk of heart attack and stroke than other women. Until now, doctors have treated migraines with the goal of making patients comfortable, decreasing their suffering, and allowing them a higher quality of life. Some people find other ways to cope with their migraines and choose not to use medication to reduce the headaches. If migraines with aura, however, are not only painful, but also lead to higher risk of stroke and heart attack, then doctors and patients might have another very important reason to treat migraines. We do not yet know whether treatments used to prevent migraines would also reduce the risk of heart attack and stroke. If this is true, then we need to be aware that leaving migraines untreated is not only uncomfortable, but also dangerous. Awareness of increased stroke risk might also signal patients with migraines to pay special attention to other cardiovascular risk factors such as high blood pressure, high cholesterol, and smoking. 
WHAT IS MIGRAINE? A migraine headache is usually a severe, throbbing headache that is typically on one side of the head and may last for hours. It is 3 times more common in women than men. ${ }^{4}$ Often migraine headaches are accompanied by nausea and sometimes vomiting. Generally, when someone is experiencing a migraine, he or she will feel the need to lie down in a dark, quiet place until the headache ends. The cause of migraine is not well understood, but it is believed that abnormal brain or nerve activity causes blood vessels in the brain to both dilate and constrict, leading to the headache. Some migraines begin with what is called an aura. Auras usually consist of strange visions of light or color. Occasionally an aura may also involve a familiar smell or taste or weakness or numbness on one side of the body. After the aura, the migraine headache begins.

HOW COMMON IS MIGRAINE? An estimated 28 million Americans experience migraines. Specifically, that is $17 \%$ of American women and 6\% of American men. ${ }^{5}$ Headache is the most common reason why patients see a neurologist, and migraine is the most common type of headache that neurologists see.

WHAT CAUSES A MIGRAINE? The cause of migraine is not well understood, but it is believed that blood vessels in the brain both dilate and constrict, leading to the headache. During an aura, brain cells become overexcited, and this increase in brain activity leads to the blood vessel changes, which cause the headache. Sometimes the migraine disorder is hereditary, passed down through families. Often triggers such as stress, temperature changes, hormonal changes, or changes in diet cause a migraine to start.

WHAT ARE THE TREATMENTS FOR MIGRAINE? Many different medication treatments are available for migraines. Some work to stop migraines after they start. Others are taken every day to prevent future migraines. Migraine treatments have varying side effects. Depending on a patient's migraine frequency and severity and other medical conditions, doctors may recommend different migraine medications. Certain types of mental health counseling aimed at reducing stress levels to control headaches may also help reduce migraines.

\section{FOR MORE INFORMATION}

National Headache Foundation

http://www. headaches.org/

M.A.G.N.U.M. The National Migraine Association

http://www.migraines.org/

National Institutes of Health, National Institute of Neurological Disorders and Stroke

www.ninds.nih.gov/health_and_medical/disorders/headache.htm

\section{REFERENCES}

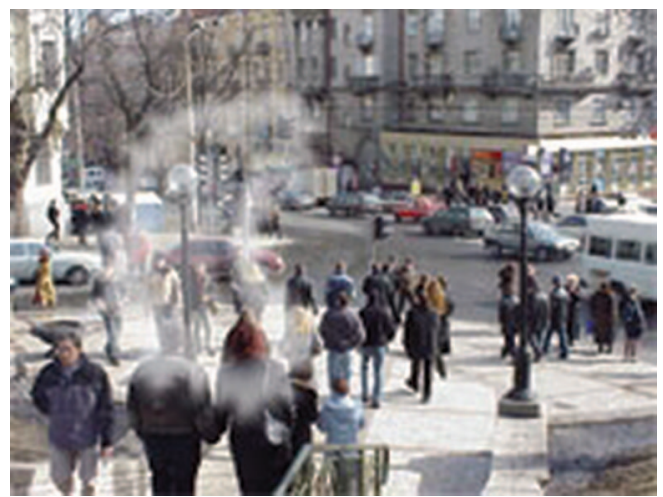

This "scintillating scotoma" is a common type of migraine aura. Courtesy of UW Medicine.
1. Merikangas KR, Fenton BT, Cheng SH, Stolar MJ, Risch $\mathrm{N}$. Association between migraine and stroke in a largescale epidemiological study of the United States. Arch Neurol 1997;54:362-368.

2. Kurth T, Gaziano M, Cook N, Logroscino G, Diener HC, Buring J. Migraine and risk of cardiovascular disease in women. JAMA 2006;296:283-291.

3. Kurth T, Schürks M, Logroscino G, Buring JE. Migraine frequency and risk of cardiovascular disease in women. Neurology 2009;73:581-588.

4. Stewart WF, Lipton RB, Celentano DD, Reed ML. Prevalence of migraine headache in the United States. JAMA 1992;267:64-69.

5. Lipton RB, Scher AI, Kolodner K, Liberman J, Steiner TJ, Stewart WF. Migraine in the United States: epidemiology and patterns of health care use. Neurology 2002;58:885-894. 


\section{Neurology}

\section{Migraine frequency and risk of cardiovascular disease in women Eve Klein and David Spencer \\ Neurology 2009;73; 42 -e43 \\ DOI 10.1212/WNL.0b013e3181b7c1d8}

This information is current as of August 24, 2009

\section{Updated Information \& Services}

References

Permissions \& Licensing

Reprints including high resolution figures, can be found at: http://n.neurology.org/content/73/8/e42.full

This article cites 5 articles, 2 of which you can access for free at: http://n.neurology.org/content/73/8/e42.full\#ref-list-1

Information about reproducing this article in parts (figures,tables) or in its entirety can be found online at:

http://www.neurology.org/about/about_the_journal\#permissions

Information about ordering reprints can be found online: http://n.neurology.org/subscribers/advertise

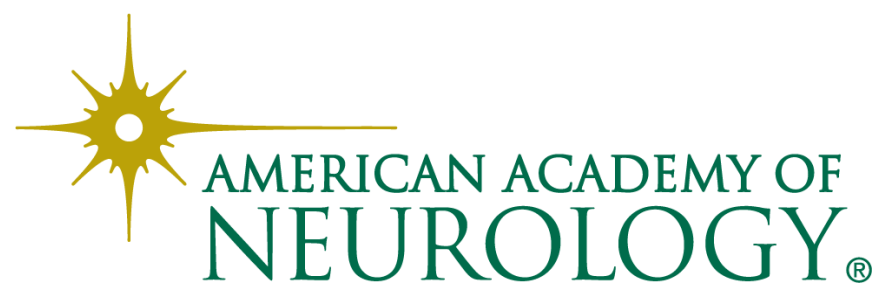

